\title{
Physical-physiological quality and early performance of sorghum plants under different boron doses via seed
}

\section{Qualidade física e fisiológica e desempenho inicial de plântulas de sorgo sob diferentes doses de boro via semente}

\author{
Vanessa Aparecida Pereira Batista1*; Henrique Duarte Vieira²; José Inácio Coelho \\ Pires $^{3}$; Laísa Zanelato Correia ${ }^{3}$
}

\section{Highlights}

Boron coating helps delay seed deterioration.

Boron doses improve seed vigor.

Boron application has a positive effect on early sorghum performance.

\section{Abstract}

Boron (B) deficiency is commonly found in tropical crops, among which sorghum stands out for its limited yield under B shortage. However, as a micronutrient, the range between its adequate and toxic levels is narrow, thus fertilization should be cautiously applied. Our goal was to evaluate the physiological and physical quality, as well as early performance, of grain sorghum seedlings under different B doses applied via seeds. Treatments consisted of six doses of boric acid $\left(0.0,2.5,5.0,7.5,10.0\right.$, and $12.5 \mathrm{~g} \mathrm{Kg}^{-1}$ seeds) plus a control (uncoated seeds). Boron doses were applied to seeds by coating, in which dolomitic limestone and glue were used for pellet formation. Coated seeds were assessed for physical, physiological, and nutritional characteristics in the laboratory, and early seedling performance was evaluated in a greenhouse. Seed tests were carried out in a fully randomized design, while seedling evaluations were carried out in a randomized block design. Boron application to seeds had no significant effect on seed physical characteristics, despite increases in coated seed sizes. Boron doses had a negative effect on the length and dry mass accumulation of both plant shoot and root. Seed-applied B accumulated mainly in roots and significantly interfered with $\mathrm{Ca}$ and $\mathrm{Mg}$ accumulations in sorghum seeds, shoots, and roots.

Key words: Fertilization. Sorghum bicolor. Vigor. Physiology. Pellet.

1 PhD Student in the Department of Crop Production at the Universidade Estadual do Norte Fluminense Darcy Ribeiro, UENF, Campos dos Goytacazes, RJ, Brazil. E-mail: vanessabaptsta@gmail.com

2 Prof. Dr., Department of Crop Production, UENF, Campos dos Goytacazes, RJ, Brazil. E-mail: henrique@uenf

3 Master's Student in the Department of Crop Production, UENF, Campos dos Goytacazes, RJ, Brazil. E-mail: inacio. fjv@hotmail.com; laisa1102@gmail.com

* Author for correspondence

Received: Mar. 24, 2021 - Approved: July 21, 2021 


\section{Resumo}

O boro é um dos nutrientes que mais promovem deficiência nas culturas das regiões tropicais, dentre elas o sorgo se destaca por ter seu rendimento limitado em condições de insuficiência de boro. Entretanto, por ser um micronutriente o boro apresenta limite estreito entre o teor adequado e o nível de toxicidade sendo exigido uma adubação cautelosa. Objetivou-se avaliar a qualidade fisiológica e física e o desempenho inicial de mudas de sorgo granífero submetidas a diferentes doses de boro via sementes. Foram utilizadas seis doses de ácido bórico (0; 2,5; 5,0; 7,5; 10,0; $12,5 \mathrm{~g}$. Kg-1 de sementes) mais o tratamento controle (sementes não revestidas). As doses de B foram adicionadas às sementes através do processo de revestimento, onde foi utilizado calcário dolomítico e a cola na formação do pelete. Foram realizadas avaliações físicas, fisiológicas e nutricionais das sementes revestidas e o desenvolvimento inicial das plantas em casa de vegetação. Os testes realizados em laboratório foram conduzidos em delineamento inteiramente casualizado e os realizados em casa de vegetação foram em delineamento de blocos ao acaso. A aplicação de B nas sementes não afetou significativamente as características físicas, entretanto houve incrementos no tamanho das sementes revestidas. As doses de $\mathrm{B}$ aplicadas às sementes de sorgo influenciaram negativamente no comprimento e acúmulo de massa seca tanto da parte aérea como da raiz das plantas. O B aplicado nas sementes acumulou-se principalmente nas raízes e interferiu significativamente no acúmulo de Ca e Mg nas sementes, parte aérea e raiz das plantas de sorgo.

Palavras-chave: Fertilização. Sorghum bicolor. Vigor. Fisiologia. Pélete.

\section{Introduction}

Boron (B) deficiency is an important agricultural issue in more than 80 countries. This micronutrient is one of the most limiting to crop yield, especially for demanding species grown in sandy soils, where it can be lost by leaching due to its high mobility in soil (Uraguchi \& Fujiwara, 2011). Several studies have targeted $B$ due to its functions in plant metabolism. Among its roles, this element is relevant to increase seed yield and quality. It also takes part in cell growth, nucleic acid formation, nitrogen fixation, aluminum toxicity reduction, cell wall biosynthesis, sugar translocation, as well as in flowering and pollen tube growth. Given all this, B has an outstanding relevance in agricultural production (Marschner, 2012).

Sorghum (Sorghum bicolor) is the fifth most grown cereal worldwide. This crop has great importance in the world scenario due to its agronomic characteristics such as high photosynthetic capacity, high biomass production potential, and wide edaphoclimatic adaptation. These features allow it to produce even under unfavorable conditions when compared to most other cereals. Sorghum can also be used for human and animal food, as well as bioenergy production (Ribas, 2014). Despite its good performance under stress, sorghum is a nutrient demanding crop. Its nutritional demands vary directly with production potential (Magalhães et al., 2014), especially micronutrients that are required in minute amounts. Among micronutrients, B deficiency can significantly reduce productivity, which, therefore, can be improved with good nutritional management.

As micronutrients are required in small amounts by plants, seed coating becomes a practical reality for various applications. 
This is because such a technique promotes lower application costs, improved distribution uniformity for small doses, lower losses, and better use by plants (Prado, Romualdo, \& Rozane, 2008; Acha, Vieira, Souza, \& Silva, 2018). Micronutrient-enriched seeds are used to further translocate these elements to the future plant, increasing the initial levels of micronutrients. Therefore, these enriched seeds serve as a source of nutrition for plants (Pessoa, Luchese, \& Luchese, 2000).

Another important factor is the adequate dose, as $B$ has a narrow range between adequate and toxic levels. This, therefore, requires cautious fertilization to avoid germination decrease and delay, and hence yield reduction (Marschner, 2012).

Based on the above, our objective was to evaluate the physiological-physical quality and early performance of grain sorghum seedlings under different doses of B via seeds.

\section{Material and Methods}

The study was carried out at the Department of Crop Production, State University of Norte Fluminense 'Darcy Ribeiro,' Campos dos Goytacazes - RJ (Brazil), between October and December 2018. Experiments were performed under laboratory conditions and in a greenhouse, arranged in fully randomized and randomized block designs, respectively.

We used commercial grain sorghum (hybrid PR40G34) seeds. They were coated and treated with six doses of boric acid $\left(\mathrm{H}_{3} \mathrm{BO}_{3}\right)$ $\left(0.0,2.5,5.0,7.5,10.0,12.5 \mathrm{~g} \mathrm{Kg}^{-1}\right.$ seeds) plus a control (uncoated seeds). Seeds were coated by a method adapted from Xavier, Vieira and Guimarães (2015), using a bench dredge N10
Newpack equipped with a stainless-steel bowl, speed regulation, control of cementing material spray, and drying system. The dredger was adjusted so that the steel tank rotates at a speed of $86 \mathrm{rpm}$ and compressed-air pressure of 4 bar, activating the cementing solution for $3 \mathrm{~s}$, and then a hot-air fan was turned on at $50{ }^{\circ} \mathrm{C}$ for $90 \mathrm{~s}$. As for filling material, we used dolomitic limestone, and as cementing material, a solution of glue based on polyvinyl acetate (PVA) and water previously heated to $70^{\circ} \mathrm{C}$ at a 3: 1 ratio.

The coating was carried out four times per treatment, using $100 \mathrm{~g}$ seed portions each. First, the seed portions were placed into the dredger tank. After, the adhesive solution was sprayed for $3 \mathrm{~s}$, and then part of the filling material (initially $10 \mathrm{~g}$ of material) was added to the tank. Soon after, the adhesive solution was again sprayed (3s) followed by the addition of another portion of the filling material $(10 \mathrm{~g})$, which was stuck to the seeds after another adhesive solution spray (3s). Right after, the air blower $\left(50^{\circ} \mathrm{C}\right)$ was activated for $90 \mathrm{~s}$. This procedure resulted in the first coating layer. For the next layer, the adhesive solution was again sprayed followed by another addition of filling material, then another adhesive solution spray and the remaining filling material. Finally, another adhesive solution spray was applied, before triggering the final hot air, which lasted $90 \mathrm{~s}$. This procedure was repeated until the $200 \mathrm{~g}$ filling material was fully finished, totaling 10 coating layers. Boric acid $\left(\mathrm{H}_{3} \mathrm{BO}_{3}\right)$ doses were added at once, in the fifth coating layer, between dolomitic limestone and glue.

After coating, seeds were evaluated for physical, physiological, and nutritional quality. Seed physical properties were performed in the laboratory and consisted of seed biometrics (Seed Analysis System; 
Groundeye $\left.{ }^{\circledR}\right)$, with four 50 -seed replications per treatment. The variables measured were maximum diameter (MAD), minimum diameter (MID), and total seed area (TSA), and results expressed in centimeters (cm).

The physiological evaluations comprised: 1) Germination Test (G\%) with four 50 seed repetitions on a Germitest towel paper moistened with water to 2.5 times the dry paperweight. After sowing, the papers were kept in a germinator at $20-30{ }^{\circ} \mathrm{C}$ under 8 h light/16 h darkness photoperiod. The evaluations were carried out on the 10th day after sowing, recording the percentage of normal seedlings (Ministério da Agricultura, Pecuária e Abastecimento [MAPA], 2009); 2) First Germination Count (FGC), which was performed four days after the beginning of $\mathrm{G} \%$, counting the number of normal seedlings, with results expressed as a percentage (MAPA, 2009); 3) Germination Speed Index (GSI), which was done together $\mathrm{G} \%$ and started after the beginning of $\mathrm{G} \%$, consisting of daily counts of germinated seeds, wherein only seedlings showing normal characteristics (MAPA, 2009) were considered, using the formula proposed by Maguire (1962); 4) Accelerated Aging (AA), which was performed in Gerbox boxes with a metallic screen fixed in the median position, adding $40 \mathrm{~mL}$ distilled water to the bottom of each box and distributing the seeds of each treatment into uniform layers on the screen, forming a single layer; the boxes containing seeds were then covered and placed in a BOD type incubator at $41^{\circ} \mathrm{C}$, wherein they remained for 72 hours (Marcos, 2016); afterwards, the seeds were submitted to G\% as previously described; this evaluation was carried out seven days after sowing, and results expressed as a percentage.
In the greenhouse test, the following characteristics were evaluated: 1) Emergence test (E\%), which was conducted with four 50 seed replications, using $8 \mathrm{~L}$ pots containing previously washed sand. To do so, seeds were distributed in $3 \mathrm{~cm}$ deep furrows spaced $2 \mathrm{~cm}$ apart. The substrate received daily irrigations and, at 15, 30, and 45 days after sowing, $500 \mathrm{~mL}$ of $25 \%$ complete nutrient solution, devoid of $B$, was applied to each pot. The final evaluation of seedlings was carried out 60 days after sowing; (Batista, Vieira, Pires, Baroni, \& Silva, 2020). 2) Emergence Speed Index (ESI), which was conducted together with $\mathrm{E} \%$, was determined by daily counting of emerged seedlings (i.e., showing cotyledons above the surface of the substrate), from the beginning until the 30th day after sowing. ESI was calculated by the formula proposed by Maguire (1962).

After E\%, 10 plants from each experimental unit were selected and split into shoot and root, which were measured for length using a millimeter rule. Then, they were stored in paper bags and placed in an air circulation oven at $65^{\circ} \mathrm{C}$ for 72 hours for further dry mass measures (Batista et al., 2020). Seeds were also dried at $65^{\circ} \mathrm{C}$ for 72 hours.

After drying, nutrient contents in seeds and other plant parts were determined. Seeds were macerated in a crucible and plant shoot and root ground in a Wiley-type mill (1 $\mathrm{mm}$ sieves). Later, samples were kept in hermetically closed and properly identified flasks. Calcium (Ca), magnesium ( $\mathrm{Mg}$ ), and boron (B) contents were measured on four 100 mg repetitions for each treatment. Then, the materials underwent digestion with nitric acid (Peters, 2005), and the extract was using an ICPE-9000 spectrometer (Shimadzu, Japan). 
All data obtained were subjected to analysis of variance, and treatment means were compared to control by the Dunnett's test at $5 \%$ probability (combining coating and $B$ doses). A regression analysis was carried out to study B doses, using the SAEG statistical software.

\section{Results and Discussion}

Boron (B) doses had no significant effect on all seed physical properties (Table 1). Table 1 shows that the averages of control treatment were, on average, 11,10 , and $18 \%$ lower than those of treatments for MAD, MID, and TSA, respectively. These parameters are related to seed geometry (Figure 1) and are responsible for describing the region occupied by the seed in the image plane (Acha \& Vieira, 2020). In short, all treatments increased seed size during coating, which added filling material (dolomitic limestone) and B doses to their surface. This, therefore, changed seed shape, justifying the higher sizes when compared to control seeds.

Conversely, these physical traits had no significant differences at $7.5 \mathrm{~g} \mathrm{~kg}^{-1} \mathrm{~B}$, and only for MAD, at $12.5 \mathrm{~g} \mathrm{~kg}^{-1} \mathrm{~B}$ (Table 1). These treatments were then poorly effective in coating adhesion. Our results corroborate the findings by Acha, Vieira and Freitas (2016), who observed that coating perennial soybean seeds with zinc $(\mathrm{Zn})$ and $B$ doses impaired seed quality.

As coating thickness increases, seeds are more protected against pest attack, both in the field and in storage, delaying their deterioration (Gardarin, Durr, Mannino, Busset, \& Colbach, 2010). Coating thickness is also a key factor to add fertilizers, fungicides, and other agricultural additives, which must be placed far from the embryo to avoid toxicity (Acha \& Vieira, 2020).

Regarding G\%, FGC, GSI, and AA, B doses had significant effects, with a decreasing linear model best fitting the data (Figure 2). For $\mathrm{G} \%$, maximum percentages were observed in seeds coated only with dolomitic limestone (88.5\%), followed by a B dose of $2.5 \mathrm{~g} \mathrm{~kg}^{-1}(86 \%)$, from which percentages decreased (Figure 2A). Similar results were observed by Pessoa et al. (2000), who applied different B doses (0, $1,2,3$, and $4 \mathrm{~g} \mathrm{~kg}^{-1}$ ) to corn seeds and found that seeds treated with increasing $B$ doses decreased in size and had a germination delay. They also observed germination unevenness and low early development of plants as B doses increased. 
Table 1

Maximum diameter (MAD), minimum diameter (MID), and total area (TSA) of grain sorghum seeds coated with dolomitic limestone as a function of boron doses $\left(\mathrm{g} \mathrm{kg}^{-1}\right)$. Campos dos Goytacazes, RJ (Brazil), 2018

\begin{tabular}{|c|c|c|c|}
\hline \multirow{2}{*}{ Treatment } & \multicolumn{3}{|c|}{ Evaluated parameter } \\
\hline & MAD & MID & TSA \\
\hline & \multicolumn{2}{|c|}{$\ldots \ldots \ldots \ldots . . .(\mathrm{cm})$} & $\ldots . .\left(\mathrm{cm}^{2}\right) \ldots$ \\
\hline Control & 0.475 & 0.425 & 0.162 \\
\hline 0.0 & $0.550^{*}$ & $0.482^{*}$ & $0.207^{*}$ \\
\hline 2.5 & $0.525^{*}$ & $0.465^{*}$ & $0.192^{*}$ \\
\hline 5.0 & $0.525^{*}$ & $0.470^{*}$ & $0.192^{*}$ \\
\hline 7.5 & 0.512 & 0.460 & 0.190 \\
\hline 10.0 & $0.542^{*}$ & $0.497^{*}$ & $0.212^{*}$ \\
\hline 12.5 & 0.520 & $0.472^{*}$ & $0.192^{*}$ \\
\hline F-test & $0.3157^{\text {ns }}$ & $0.2346^{\text {ns }}$ & $0.2188^{\text {ns }}$ \\
\hline Linear regression & ns & ns & ns \\
\hline Quadratic regression & ns & ns & ns \\
\hline
\end{tabular}

*, ns: significant and non-significant by the F-test at $5 \%$ probability, respectively. * Asterisked means in the column are different from the control at $5 \%$ probability by the Dunnett's test.
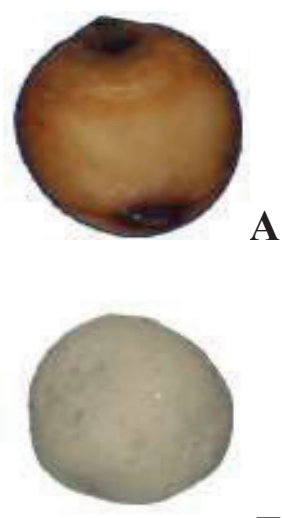

E

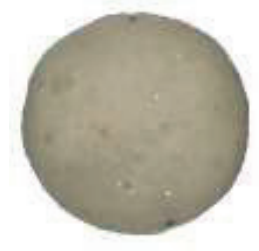

B

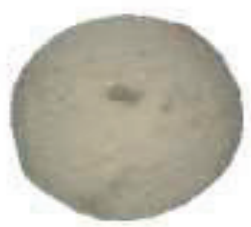

F

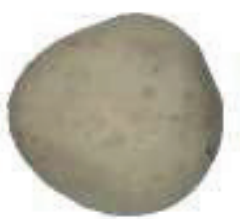

C

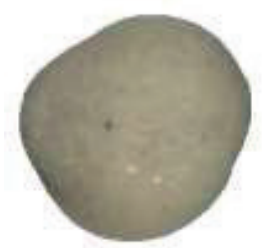

D

Figure 1. Sorghum seeds: A) Intact seed; B) Dolomitic limestone coating; C) Dolomitic limestone + $2.5 \mathrm{~g} \mathrm{~kg}^{-1} \mathrm{~B}$; D) Dolomitic limestone + $5.0 \mathrm{~g} \mathrm{~kg}^{-1} \mathrm{~B}$; E) Dolomitic limestone $+7.5 \mathrm{~g} \mathrm{~kg}^{-1} \mathrm{~B}$; F) Dolomitic limestone $+10.0 \mathrm{~g} \mathrm{~kg}^{-1} \mathrm{~B}$; G) Dolomitic limestone $+12.5 \mathrm{~g} \mathrm{~kg}^{-1}$ B. Campos dos Goytacazes, RJ (Brazil), 2018.

Vigor tests (FGC, GSI, and AA) also showed reductions in normal seedling percentages and seed viability with increasing B doses, confirming B potential toxicity. High $B$ levels in plant tissues can alter enzymatic reactions and trigger metabolic changes, activating defense mechanisms. This sort of stress accumulates ROS (reactive oxygen species), such as superoxide radicals, hydroxides, and hydrogen peroxides $\left(\mathrm{H}_{2} \mathrm{O}_{2}\right)$. 
These, in turn, cause oxidative stress on plant biological molecules, resulting in cell death (Nejad and Etesami, 2020). Our results corroborate those of Lima et al. (2013), which showed that B doses above $1.5 \mathrm{~kg}$ $\mathrm{ha}^{-1}$ decrease common bean seed vigor due to toxicity effects. These data are extremely important because, even at high germination rates, low-vigor seeds reduce field yield when under unfavorable conditions (Krzyzanowski, Vieira, \& França, 1999).

B
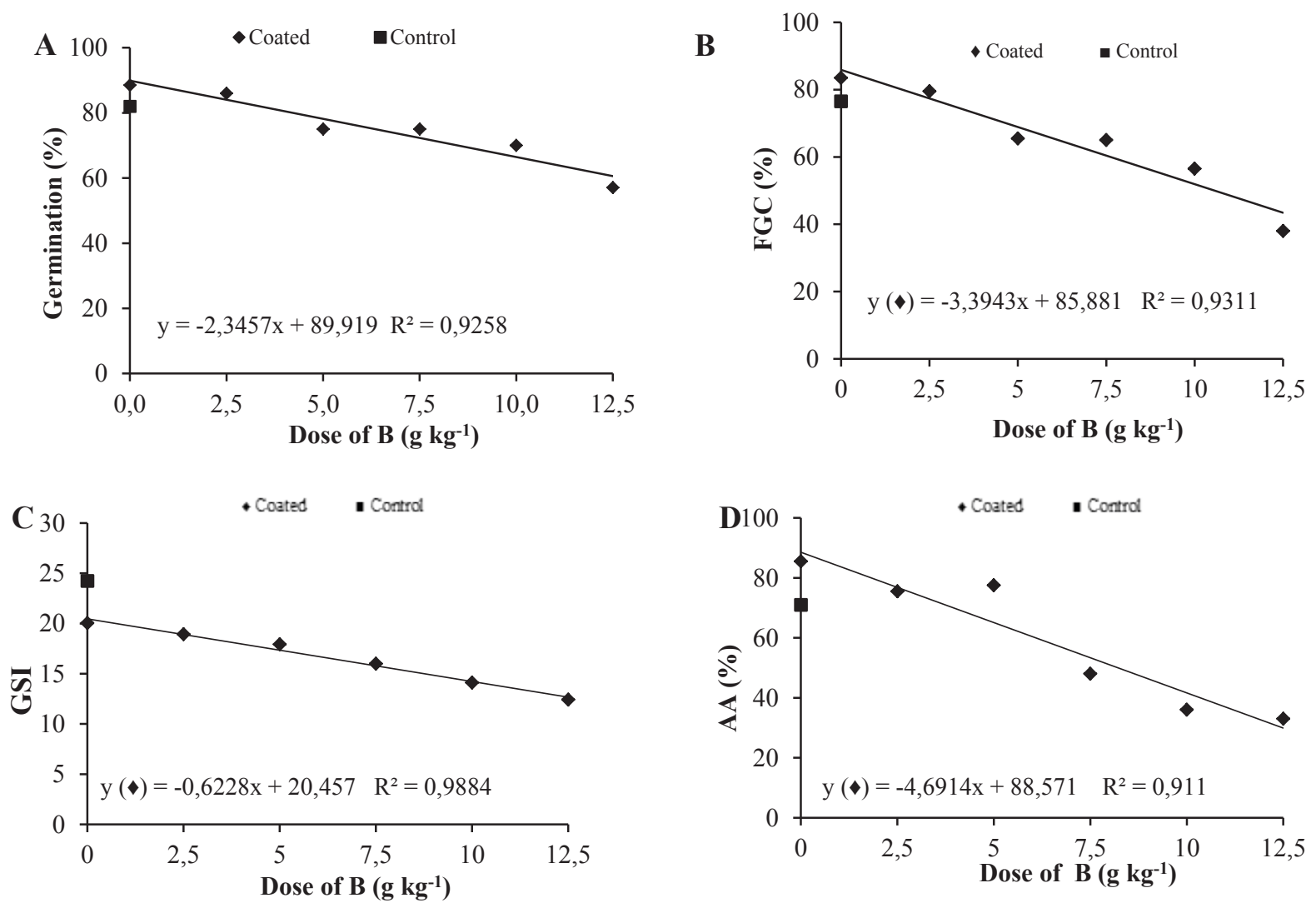

Figure 2. Germination (A), first germination count (B), germination speed index (C); and accelerated aging (D) of grain sorghum seeds coated with dolomitic limestone and different doses of boron. Campos dos Goytacazes, RJ (Brazil), 2018.

By contrast, FGC and AA tests showed that coating with only dolomitic limestone acted positively on sorghum seed vigor since the coated seeds had a higher average of normal seedlings than the other treatments, even than the control (Figure 2B, 2D). Similar results were observed by T. R. B. Silva, Soratto, Bíscaro and Lemos (2008), who verified via FGC and electrical conductivity tests that calcium application increased common bean seed vigor. It may be because calcium increases plant tegument resistance, protecting against biotic and abiotic stresses. Besides acting in the formation and integrity of cell wall membranes, calcium is important in root development and cell extension and plays 
a major role in the translocation and storage of carbohydrates and proteins (Singh, 2020).

Figure $2 \mathrm{C}$ shows that control seeds had higher normal seedling means in the FGC test. This is mainly due to an additional physical barrier formed around coated seeds, which makes exchanges between seed and environment difficult. Hence, this delays germination and early seedling development. These results agree with Acha et al. (2016) and Silva, Vieira, Baroni, Maitan and Acha (2017), who reported that coated seeds take longer to germinate than uncoated seeds by a physical barrier formed by coating.
A quadratic model best fit the ESI data, with a coefficient of determination of 96\% (Figure 3A). The seedlings in the control treatment reached higher ESI (8.6), followed by coated seeds without B application (5.46). These results agree with GSI findings (Figure 2C). Therefore, seed coating formed an additional barrier in the integument, which delayed seedling emergence. Moreover, the increasing $B$ doses may have promoted a phytotoxic effect, decreasing emergence speed.
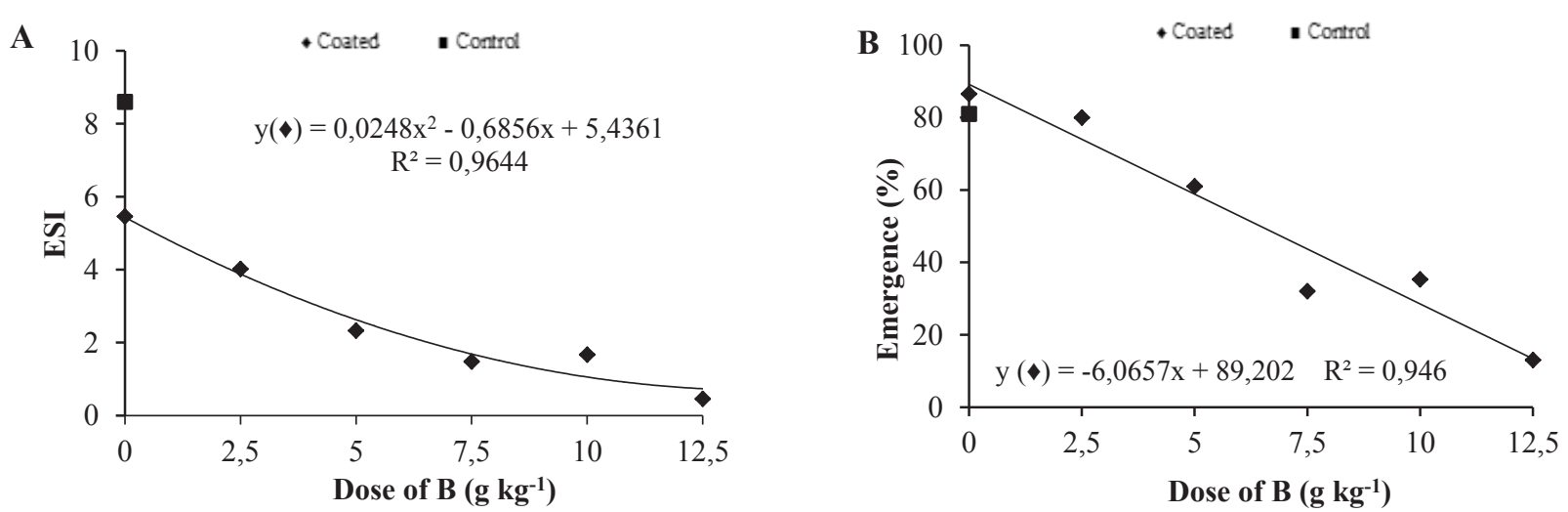

Figure 3. Emergence speed index (A) and emergence (B) of grain sorghum seeds coated with dolomitic limestone and different doses of boron. Campos dos Goytacazes, RJ (Brazil), 2018.

A decreasing linear model best fitted the emergence data, with a coefficient of determination of $94 \%$ (Figure 3B). Seedlings from seeds coated only with dolomitic limestone reached maximum emergence (86\%). There was also a decrease of 6 percentage points per unit of applied B dose. The effect of $\mathrm{B}$ doses was also more expressive on seedling emergence than on the seed germination test. The highest $\mathrm{B}$ dose
(12.5 $\mathrm{g} \mathrm{kg}^{-1}$ ) promoted only $13 \%$ seedling emergence, while for germination, it showed $57 \%$ normal seedlings (Figure 2A). This result may be associated with the conditions under which the emergence test was carried out. The test was performed inside a greenhouse with seeds placed to germinate in sand pots, simulating field conditions, e.g., variable temperature, low moisture retention in the substrate, requiring thus constant irrigation. 
These conditions, added to the B dose effect, may have stressed seeds, and hence affect their capacity to give rise to normal seedlings.

It is noteworthy that high $B$ concentrations cause deleterious effects on plant growth and development. Furthermore, B toxicity inhibits germination of several plant species, reduces root and stem growths, inhibits cell expansion, and affects photosynthesis, causing damage to thylakoid assembly and thus reducing $\mathrm{CO}_{2}$ absorption (Uluisik, Karakaya, \& Koc, 2018).

Regarding shoot length (SL), root length (RL), shoot dry mass (SDM), and root dry mass (RDM), $B$ doses had a significant effect (Figure 4). SL had a quadratic behavior and maximum efficiency at $2.58 \mathrm{~g} \mathrm{~kg}^{-1} \mathrm{~B}(40.5$ $\mathrm{cm}$ ) but decreased at higher doses (Figure $3 A)$. These results corroborate those found by Silva-Matos et al. (2017), who observed growth of watermelon seedlings up to a dose of $11.66 \mathrm{~g} \mathrm{~kg}^{-1} \mathrm{~B}$, followed by a decrease with increasing doses.

A linear decreasing behavior was observed for RL. However, the dose of 2.5 $\mathrm{g} \mathrm{kg}^{-1}$ promoted an increase in $\mathrm{RL}$, with the highest value in the control without $B$ addition (Figure 4B). These results corroborate SilvaMatos et al. (2017), who found a significant effect of B doses, applied via seed, on RL of watermelon seedlings, increasing up to a dose of $15.75 \mathrm{~g} \mathrm{~kg}^{-1}$, and then decreasing.
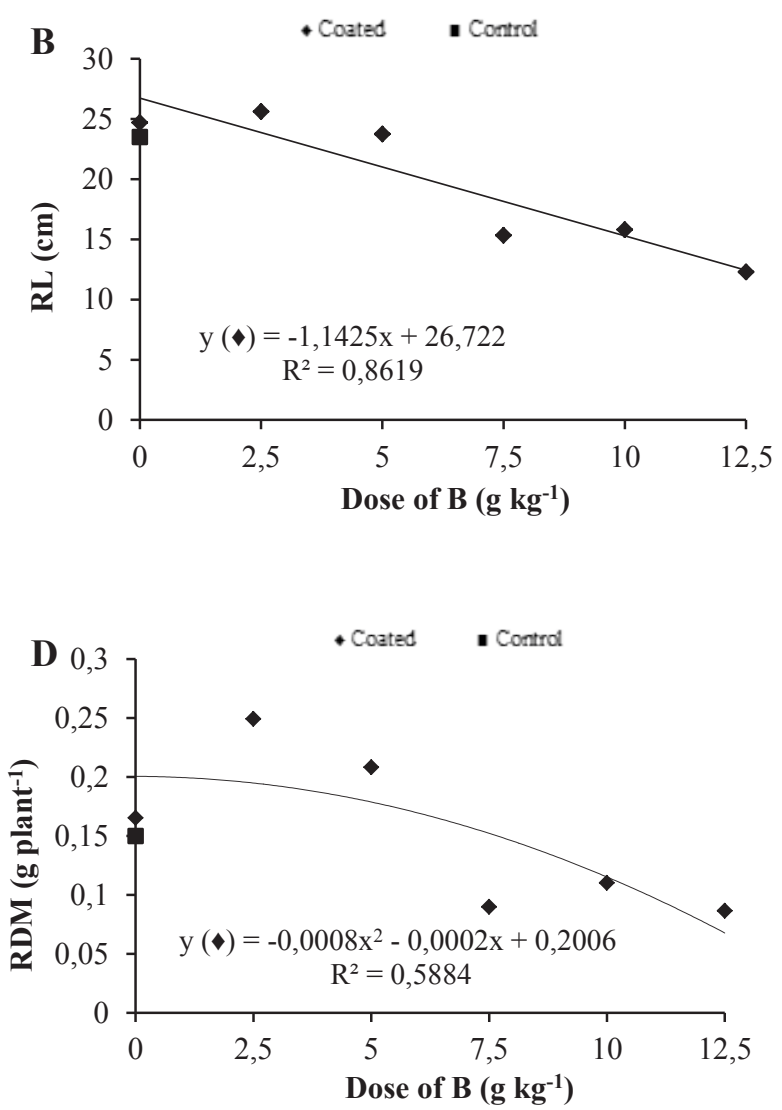

Figure 4. Shoot length (A), root length (B), shoot dry mass (C), and root dry mass (D) of grain sorghum seeds coated with dolomitic limestone and different doses of boron. Campos dos Goytacazes, RJ (Brazil), 2018. 
Seeds treated with B doses above 2.5 $\mathrm{g} \mathrm{kg}^{-1}$ showed a decrease in SDM and RDM (Figure 4C and 4D). Likewise, Pessoa et al. (2000) observed that maize seeds treated with $B$ doses equal to or greater than $0.2 \mathrm{~g} \mathrm{~kg}^{-1}$ had a decrease in leaf and root dry masses. When applying B to melon seeds, Albano et al. (2015) found that an increase in $B$ doses increased shoot dry mass up to $12.3 \mathrm{~g} \mathrm{~kg}^{-1}$ seed, followed by a small decrease with increasing $B$ doses. The same authors observed that root dry mass increased at a dose of $10.5 \mathrm{~g} \mathrm{~kg}^{-1} \mathrm{~B}$, and above that, it reduced.

The positive effect of $B$ application on seedling growth up to a dose of $2.5 \mathrm{~g} \mathrm{~kg}^{-1}$ (Figure 4) can be explained by $B$ functions in plants. An adequate B supply promotes cell elongation, nucleic acid synthesis, hormonal responses, membrane functioning, and cell cycle regulation, directly stimulating the elongation of plant young parts (Marschner, 2012). However, germinating seeds do not have physiological mechanisms to effectively control the entry of $B$, via seed imbibition. This can result in $B$ accumulation at toxic concentrations, causing phytotoxicity and deleterious effects on germination and plant development (Reguera, Espi, Bolanos, Bonilha, \& Redondonieto, 2009, Ohse, Morodim, Santos, Lopes, \& Mafron, 2001).

In this sense, Demiray and Dereboylu (2013) stated that high B doses significantly reduce root tissue lignification and negatively the formation of the xylem. Such characteristics directly and negatively influence root development. Thus, the decreasing effect on RDM may be related to a decreasing effect observed on RL (Figure 4), since $R L$ directly influences nutrient absorption and contributes representatively in total dry mass, and consequently SL and SDM.

Boron doses applied in coating significantly affected its contents in sorghum seeds, shoots, and roots. In seeds, a quadratic model best fitted to the data, in which the highest dose (12.5 $\mathrm{g} \mathrm{kg}^{-1}$ ) promoted content of $497.5 \mathrm{mg} \mathrm{B} \mathrm{kg}^{-1}$ seed. In seeds of the control and those coated only with dolomitic limestone, B contents were 4.03 and $5.11 \mathrm{mg}$ $\mathrm{kg}^{-1}$ seed, respectively (Figure 5A).

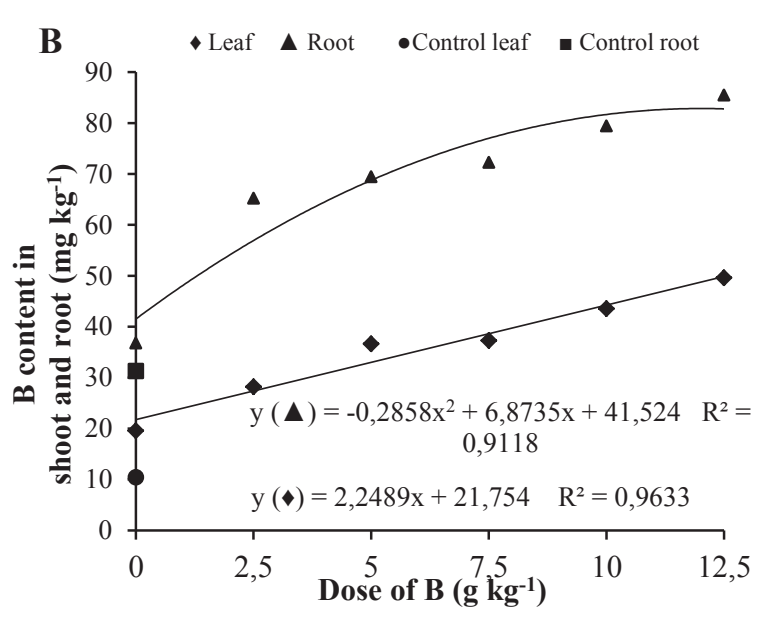

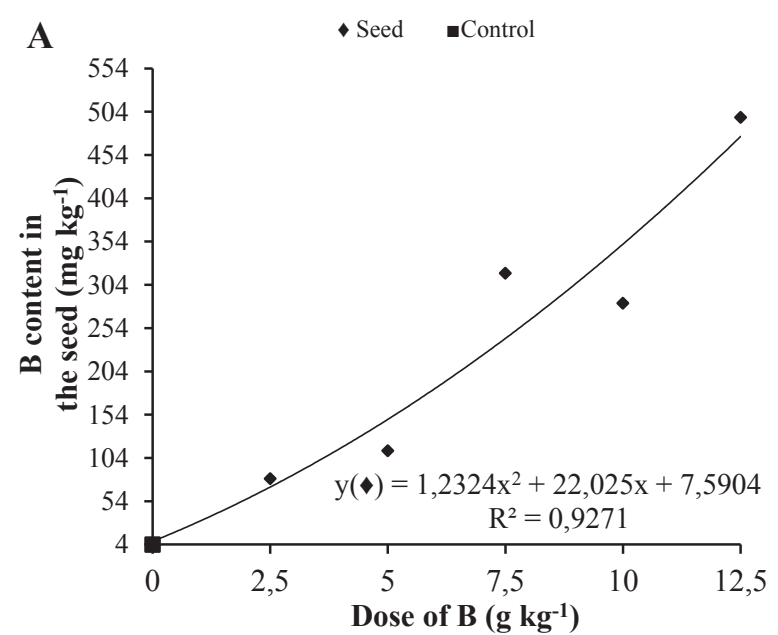

Figure 5. Boron content in seeds (A), shoot, and root (B) of grain sorghum seeds coated with dolomitic limestone and different doses of boron. Campos dos Goytacazes, RJ (Brazil), 2018. 
After coating, B content in seeds increased proportionally to the increase in $B$ dose. Therefore, the technique used in this study was efficient to incorporate this micronutrient into seeds. These results corroborate Acha and Vieira (2020), who coated Brachiaria seeds with $B$ and $Z n$ doses and found an increase in their content as fertilizer doses were raised.

Sorghum seedling shoot showed an increasing linear behavior, increasing by 2.25 $\mathrm{mg} \mathrm{B} \mathrm{kg}^{-1}$ seed per unit of $B$ dose increased (Figure 5B). At the maximum dose (12.5 g B $\left.\mathrm{kg}^{-1}\right), \mathrm{B}$ content in the shoot was $49.60 \mathrm{mg} \mathrm{kg}^{-1}$. These results are like the findings of Acha et al. (2018) in perennial soybean seeds treated with $B$ and $\mathrm{Zn}$ doses. They observed that an increase in $B$ dose promoted an increase in its content in plant shoot, thus evidencing its high absorption during seed imbibition.

Boron doses had a quadratic effect on root $B$ content, with a maximum of $85.48 \mathrm{mg}$ $\mathrm{kg}^{-1}$ of $\mathrm{B}$ at a dose of $12.5 \mathrm{~g} \mathrm{~kg}^{-1}$ (Figure $5 \mathrm{~B}$ ). High $B$ levels in roots were provided by application via seeds, culminating in its accumulation in the primary root system of plants. According to Marschner (2012), this accumulation occurs when nutrients are transported by diffusion and their offer rates are greater than the absorption ones, which is consistent with our findings.

Boron distribution within plant tissues was uneven, with roots having higher levels than shoot for the same applied dose. Boron transport over long distances via xylem (i.e., from roots to leaves) occurs by mass flow of transpiration water. However, due to passive b absorption, toxic amounts can be absorbed by developing roots, causing deleterious effects to plants. At high concentrations, B represses the expression of genes encoding water transporters, triggering water stress, and directly impairing B transport to cell walls in plant shoot (Princi et al., 2016).

Moreover, B application significantly affected calcium and magnesium accumulations. Except for $\mathrm{Mg}$ in the shoot, which had a linear effect, treated seeds showed a quadratic effect on the nutrient accumulation in shoot and root (Figure 6). 

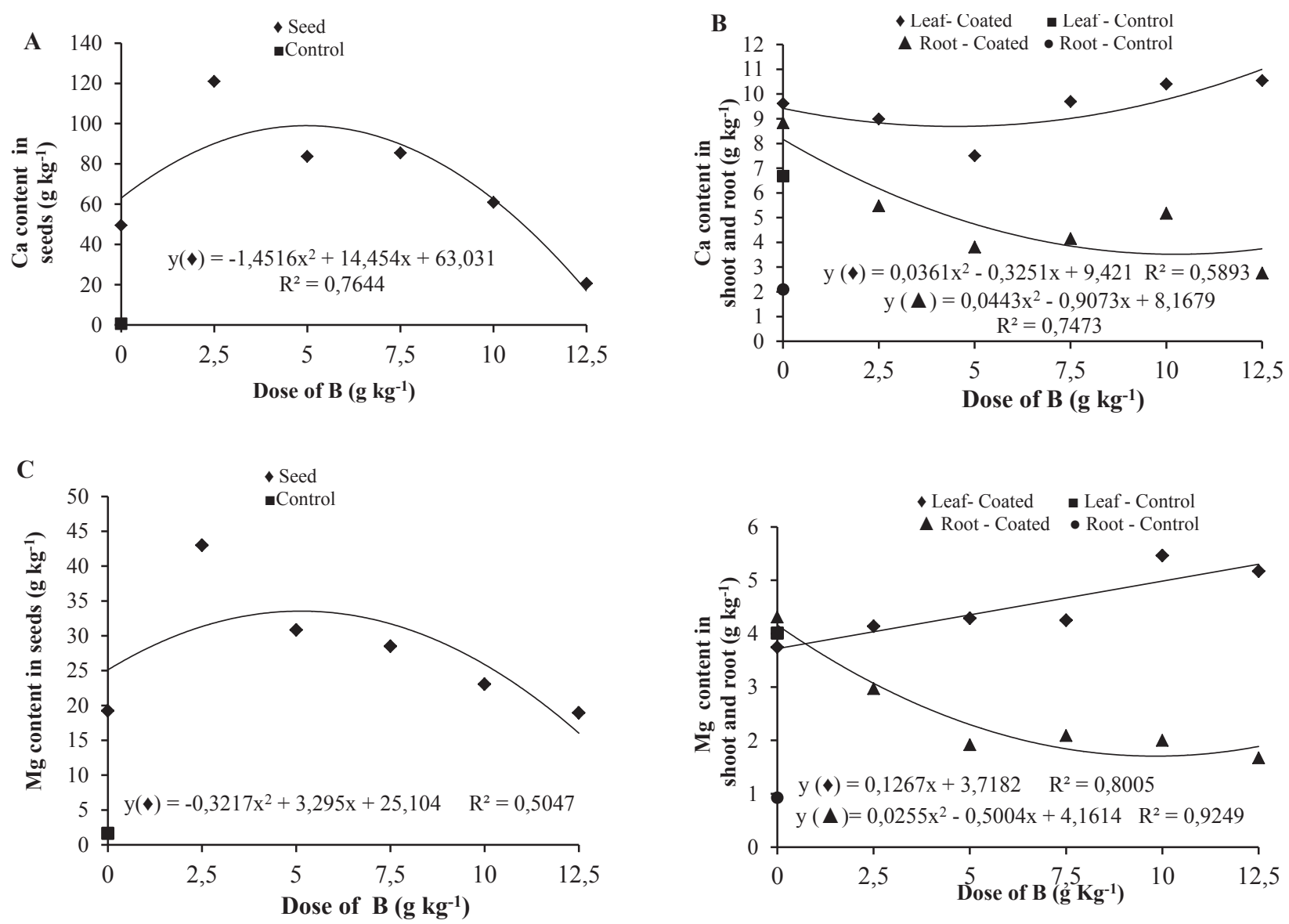

Figure 6. Effects of boron doses on contents of calcium in seeds (A), shoot, and roots (B) and magnesium in seeds (C) and shoot, and roots (D). Campos dos Goytacazes, RJ (Brazil), 2018.

Regarding coated seeds, Figure $6 \mathrm{~A}$ shows that application of $4.98 \mathrm{~g} \mathrm{~kg}^{-1} \mathrm{~B}, \mathrm{Ca}$ content reached a maximum (99 $\left.\mathrm{g} \mathrm{kg}^{-1}\right)$, decreasing thereafter. Figure $6 \mathrm{C}$ also shows that a maximum $\mathrm{Mg}$ content was $33.54 \mathrm{~g} \mathrm{~kg}^{-1}$ for a B dose of $5.12 \mathrm{~g} \mathrm{~kg}^{-1}$, also decreasing after that. These findings indicate that increases in $\mathrm{B}$ dose reduced $\mathrm{Ca}$ and $\mathrm{Mg}$ contents added to seeds. This may have been due to a decreased adhesion of dolomitic limestone to seed coating. Similar results were observed by Acha et al. (2016) when working with perennial soybean seeds coated with dolomitic limestone and different $B$ and Zn doses. These authors attribute such a result to the grain size of coating material, as boric acid has larger and heavier particles compared to dolomitic limestone. In this sense, limestone should be used in layers closer to the core so that its adhesion to the seed surface is ensured due to its weight. However, the addition of boric acid between limestone layers failed to keep them stuck together, due to the crystallized form of the acid, thus reducing limestone adhesion and hence $\mathrm{Ca}$ and $\mathrm{Mg}$ contents.

Figure 6B shows a decrease in $\mathrm{Ca}$ content in roots as $\mathrm{B}$ doses were raised. 
Araújo, Santos and Camacho (2013), when working with nutrient-solution-grown cotton seeds at different $B$ and $\mathrm{Zn}$ concentrations, observed reductions in $\mathrm{Ca}$ contents in roots as $B$ doses increased in the nutrient solution. In higher plants, B and $\mathrm{Ca}$ have similar roles in cell biosynthesis. However, $\mathrm{B}$ tends to form a stronger bond to the cell wall than does $\mathrm{Ca}$; therefore, high $\mathrm{B}$ doses may decrease $\mathrm{Ca}$ accumulation in plant tissues (Mengel \& Kirkby, 2001).

The increasing $B$ doses had a decreasing quadratic effect on $\mathrm{Mg}$ content in roots (Figure 6D), as verified by Araújo et al. (2013) and by Prado, Natale and Rozane (2006). These authors reported Mg content reductions in cotton and passion fruit roots, respectively, due to $B$ dose increases.

Boron doses had a quadratic effect on leaf $\mathrm{Ca}$ content (Figure 6B), reaching $10.45 \mathrm{~g} \mathrm{~kg}^{-1}$ for a B dose of $12.5 \mathrm{~g} \mathrm{~kg}^{-1}$. Yet, for leaf $\mathrm{Mg}$ content, it was linear, showing an increase of $0.13 \mathrm{~g} \mathrm{~kg}^{-1} \mathrm{Mg}$ for each $\mathrm{B}$ dose unit increased (Figure 6D). As no typical deficiency symptoms were observed, Ca and Mg levels in our study are within the normal limits to supply plant development. Ca-deficient sorghum has chlorosis at the plant apex, wherein tips of younger leaves gelatinize, and when dry, stick together. Yet, the lack of Mg causes a drop in chlorophyll contents, thus causing chlorosis (Coelho, Waquil, Karan, Casela, 2002).

Root morphology and efficiency of the absorption mechanisms help plants to acquire mineral elements from the environment, with a well-defined relationship among plant growth, production, and nutrient contents in tissues. Nutritional efficiency may be related to single- cell level demands, compartmentalization, shoot use, short- and long-distance transport, affinity with absorption sites, minimum concentration (Cmin), and rhizosphere changes (Marschner, 2012). Thus, increasing B supply from poor to optimal levels also affects the absorption of other nutrients, significantly interfering with plant development.

\section{Conclusion}

1) Boron application to sorghum seeds increases coated seed sizes.

2) Increasing boron doses interfere with seed physiological quality, enhancing germination and vigor up to a dose of 2.5 $\mathrm{g}$ boron per $\mathrm{kg}$ seeds, but impairing them thereafter.

3) Shoot and root length and dry mass production reduced at boron doses above 2.5 $\mathrm{g} \mathrm{kg}^{-1}$.

4) Boron applied to sorghum seeds accumulates mainly in the roots.

5) Boron doses applied via seed promote changes in calcium and magnesium contents in seeds and other sorghum plant parts.

\section{Acknowledgments}

The authors are thankful for the financial support from the Coordination for Improvement of Higher Education Personnel (CAPES), Rio de Janeiro State Research Foundation (FAPERJ), and State University of Northern Rio de Janeiro Darcy Ribeiro (UENF). 


\section{References}

Acha, A. J., \& Vieira, H. D. (2020). Digital image processing of coated perennial-soybean seeds and correlation with physiological attributes. Journal of Seed Science, 42, 1-12. doi:10.1590/2317-1545v42227516

Acha, A. J., Vieira, H. D., \& Freitas, M. S. M. (2016). Perennial soybean seeds coated with high doses of boron and zinc. African Journal of Biotechnology, 15(37), 19982005. doi: 10.5897/AJB2016.15560

Acha, A. J., Vieira, H. D., Souza, C. L. M. de, \& Silva, F. W. A. (2018). Methodology of applying different doses of boron and zinc in the coating of perennial soybean seeds. Journal of Experimental Agriculture International, 26(5), 1-9. doi: 10.9734/JE $\mathrm{Al} / 2018 / 43968$

Albano, F. G., Silva-Matos, R. R. S. da, Cavalcante, Í. H. L., Silva, R. L., Sousa Marques, A. de, \& Costa, L. S. da. (2015). Imperial melon plant seedlings initial development in function of boron doses applied in the seed. Científica, 43(4), 348352. doi: 10.15361/1984-5529.2015v43n 4p348-35

Araújo, É. D. O., Santos, E. F. dos, \& Camacho, M. A. (2013). Absorção de cálcio e magnésio pelo algodoeiro cultivado sob diferentes concentrações de boro e zinco. Revista Brasileira de Ciências Agrárias, 8(3), 383389. doi: 10.5039/agraria.v8i3a2423

Batista, V. A. P., Vieira, H. D., Pires, J. I. C., Baroni, D. F., \& Silva, F. W. A. (2020). Quality of grain sorghum seeds Coated with different combinations of materials. Journal of Experimental Agriculture International, 42(12), 26-38. doi: 10.9734/JEAl/2020/ v42i1230626
Coelho, A. M., Waquil, J. M., Karan, D., Casela, C. R., \& Ribas, P. M. (2002). Seja o doutor do seu sorgo. Informações Agronômicas, 14(100), 1-12.

Demiray, H., \& Dereboylu, A. E. (2013). Effects of excess and deficient boron and niacin on the ultrastructure of root cells in Daucus carota cv. Nantes. Turkish Journal of Botany, 37(1), 160-166. doi: 10.3906/ bot-1202-22

Gardarin, A., Durr, C., Mannino, M. R., Busset, H., \& Colbach, N. (2010). Seed mortality in the soil is related to seed coat thickness. Seed Science Research, 20(4), 243-256. doi: 10.1017/S0960258510000255

Krzyzanowski, F. C., Vieira, R. D., \& França, J. B., Neto. (1999). Vigor de sementes: conceitos e testes. Londrina, PR: ABRATES.

Lima, M. L., Cardoso, F. R., Galante, A. H. A., Teixeira, G. C. D. S., Teixeira, I. R., \& Alves, S. M. D. F. (2013). Fontes e doses de boro na qualidade de sementes de feijãocomum e mamona sob consórcio. Revista Caatinga, 26(4), 31-38.

Magalhães, P. C., Souza, T. C., May, A., Lima, O. F., Fo., Santos, F. C. dos, Moreira, J. A. A.,... Freitas, R. S. (2014). Exigências edafoclimáticas e fisiologia da produção. In A. Borém, L. D. Pimentel, \& R. Parrela (Eds.), Sorgo: do plantio à colheita (pp. 5888). Viçosa, MG: Editora UFV.

Maguire, J. D. (1962). Speeds of germinationaid selection and evaluation for seedling emergence and vigor. Crop Science, 2, 176-177.

Marcos, J., Fo. (2016). Seed physiology of cultivated plant. Londrina, PR: ABRATES. 
Marschner, P. (2012). Mineral nutrition of higher plants (3nd ed.). Oxford: Elsevier.

Mengel, K., \& Kirkby, E. (2001). Principles of plant nutrition (5nd ed.). Dordrecht: Kluwer Academic Publishers.

Ministério da Agricultura, Pecuária e Abastecimento (2009). Regras para análise de sementes. Brasília: MAPA/ACS. Recuperado de http://www.agricultura. gov.br/assuntos/insumos-agropecuarios/ arquivos-publicacoes-insumos/2946_ regras_analise_sementes.pdf

Nejad, S. A. G., \& Etesami, H. (2020). The importance of boron in plant nutrition. Metalloids in Plants: Advances and Future Prospects, 433-449. doi: 10.10 02/9781119487210.ch20

Ohse, S., Morodim, V., Santos, O. S., Lopes, S. J., \& Mafron, A. P. (2001). Germinação e vigor de sementes de arroz irrigado tratadas com zinco, boro e cobre. Revista da Faculdade de Zootecnia, Veterinária e Agronomia, 7(1), 73-79.

Pessoa, A. C. S., Luchese, E. B., \& Luchese, A. V. (2000). Germinação e desenvolvimento inicial de plantas de milho, em resposta ao tratamento de sementes com boro. Revista Brasileira de Ciência do Solo, 24(4), 939-945. doi: 10.1590/S0100-06 832000000400025

Peters, J. B. (2005). Wisconsin procedures for soil testing, plant analysis and feed \& forage analysis: plant analysis. Madison, WI: University of Wisconsin-Extension.

Prado, R. M., Natale, W., \& Rozane, D. E. (2006). Níveis críticos de boro no solo e na planta para cultivo de mudas de maracujazeiroamarelo. Revista Brasileira Fruticultura, 28(2), 305-309. doi: 10.1590/S0100-294 52006000200034
Prado, R. M., Romualdo, L. M., \& Rozane, D. E. (2008). Aplicação de zinco em sementes de sorgo cv. BRS 304: efeitos na nutrição e no crescimento inicial. Acta Scientiarum. Agronomy, 30(4), 471-478. doi: 10.4025/ actasciagron.v30i4.5300

Princi, M. P., Lupini, A., Araniti, F., Longo, C., Mauceri, A., Sunseri, F., \& Abenavoli, M. R. (2016). Boron toxicity and tolerance in plants: recent advances and future perspectives. Plant Metal Interaction, 115-147. doi: 10.1016/B978-0-12-8031 58-2.00005-9

Reguera, M., Espi, A., Bolanos, L., Bonilha, I., \& Redondonieto, M. (2009). Endoreduplication before cell differentiation fails in boron-deficient legume nodules. Is boron involved in signaling during cell cycle regulation? New Phytologist, 183(1), 8-12. doi: 10. 1111/j.1469-8137.2009.02869.x

Ribas, P. M. (2014). Origem e importância econômica. In A. Borém, L. D. Pimentel, \& R. Parrela (Eds.), Sorgo: do plantio à colheita (pp. 9-36). Viçosa, MG: Editora UFV.

Silva, F. W. A., Vieira, H. D., Baroni, D. F., Maitan, M. Q., \& Acha, A. J. (2017). Germination performance of Campo Grande (Stylosanthes capitata/macrocephala) stylers seeds coated with different layers of inert material. Journal of Experimental Agriculture International, 18(4), 1-8. doi: 10.9734/JEAI/2017/36768

Silva, T. R. B., Soratto, R. P., Bíscaro, T., \& Lemos, L. B. (2008). Aplicação foliar de boro e cálcio no feijoeiro. Científica, 34(1), 4652. doi: 10.15361/1984-5529.2006v34n $1 \mathrm{p} 46+-+52$ 
Silva-Matos, R. R. S. D., Albano, F. G., Cavalcante, Í. H. L., Pessoa, J. A., Neto, Silva, R. L, Oliveira, I. V. D. M., \& Carvalho, C. I. F. S. (2017). Desenvolvimento inicial de mudas de melancia cv. Crimson Sweet em função de doses de boro aplicadas na semente. Revista de Ciências Agrárias, 4O(4), 30-39. doi: 10.19084/RCA16121

Singh, R. (2020). Calcium in plant biology: nutrient and second messenger. International. Journal of Biological Innovations, 2(1), 31-35. doi: 10.46505/ IJBI.2020.2105

Uluisik, I., Karakaya, H. C., \& Koc, A. (2018). The importance of boron in biological systems. Journal of Trace Elements in Medicine and Biology, 45(1), 156-162. doi: 10.1002/9781119487210.ch20

Uraguchi, S., \& Fujiwara, T. (2011). Significant contribution of boron stored in seeds to initial growth of rice seedlings. Plant and Soil, 340(1), 435-442. doi: 10.1007/ s11104-010-0614-9

Xavier, P. B., Vieira, H. D., \& Guimarães, C. P. (2015). Physiological potential of Stylosanthes cv. Campo Grande seeds coated with different materials. Journal of Seed Science, 37(2), 117-124. doi: 10. 1590/2317-1545v37n2145982 